\title{
FIRST SIGNS OF CARBONIFEROUS COAL-FORMATION PROCESSES IN LVIV-VOLYN BASIN
}

\author{
V. Shulga', I. Kostyk ${ }^{2}$, M. Matrofailo ${ }^{3}$, M. Korol ${ }^{4}$
}

\section{ПЕРВЫЕ ПРИЗНАКИ ПРОЦЕССОВ КАРБОНОВОГО УГЛЕОБРАЗОВАНИЯ В ЛЬВОВСКО-ВОЛЫНСКОМ БАССЕЙНЕ

\author{
В. Шульга ${ }^{1}$, И. Костик², М. Матрофайло, Н. Король
}

Conditions of the beginning of Carboniferous coal-formation (Late Tournaisian - the beginning of Late Visean) in Lviv-Volyn basin are reconstructed. First signs of coal-formation processes are established in Late Tournaisian deposits. Process of origination of coal-bearing formation proceeded gradually and were characterised by unfavourable conditions. Appearance of environments favourable for to extension paleo-peat-bogs refers to Early Visean. Late Tournaisian deposits of Khoriv suite correspond to "germinal" period of development of coal-bearing formation of Lviv-Volyn basin, that is why its lower boundary is held in the base of the mentioned suite.

Key words: origination, coal-bearing formation, Lower Carboniferous, Khoriv suite, Kulychkiv suite, Lviv-Volyn basin.

Воссозданы условия начала карбонового углеобразования (поздний турне - начало позднего визе) в Львовско-Волынском бассейне. Первые признаки процессов углеобразования установлены в отложениях позднего турне. Процесс зарождения угленосной формации протекал постепенно и характеризовался неблагоприятными условиями. Появление обстановок, благоприятствующих распространению палеоторфяников, относится к раннему визе. Позднетурнейские отложения хоревской свиты соответствуют «зародышевому» периоду развития угленосной формации Львовско-Волынского бассейна, в связи с чем ее нижняя граница проводится по основанию указанной свиты.

Ключевые слова: зарождение, угленосная формация, нижний карбон, хоревская и куличковская свиты, Львовско-Волынский бассейн.

\section{ВСТУПЛЕНИЕ}

Реконструкция условий зарождения палеозойских угленосных формаций представляет исключительно большой интерес для познания общих закономерностей начала углеобразования на земном шаре, особенностей развития его растительного покрова, эволюции палеоклимата, определения направленности процессов осадконакопления, типов угленосных формаций и др. Однако в работах по формационному анализу угленосных отложений указанная проблема обычно освещается недостаточно полно, что прежде всего связано с ограниченным объемом фактического материала. Угольные пласты начальных этапов образования угленосных толщ, как правило, не имеют промышленного значения и не являются объектами разведочных работ. Изложенное определяет повышенный интерес к публикациям, характеризующим условия зарождения угленосных формаций и особенности их дальнейшего развития.

\section{СУЩЕСТВО ПРОБЛЕМЫ. ФАКТИЧЕСКИЙ МАТЕРИАЛ И МЕТОДИКА ИССЛЕДОВАНИЙ}

В настоящей работе сделана первая попытка восстановления условий начала карбонового (поздний турне - начало позднего визе) углеобразования в Львовско-Волынском бассейне (ЛВБ), расположенном на юго-западной окраине Восточно-Европейской платформы (ВЕП) и являющимся юго-восточным продолжением Люблинского каменноугольного бассейна Польши. Это оказалось возможным благодаря большому массиву первичной геологической информации, полученной при поисково-разведочных работах на различные виды полезных ископаемых (уголь, нефть, газ, бокситы и др.), а также бурении параметрических скважин в пределах Львовского палеозойского прогиба. Детальное изучение фактического материала позволило по-иному взглянуть на рассматриваемую проблему. При ее решении был осуществлен комплексный геолого-геофизический анализ скважин, вскрывших турнейские и ранневизейские отложения (рис. 1). Помимо фондовых материалов, использовались также данные детального литолого-фациального описания по керну скважин турнейско-визейских образований, осуществленных авторами на крайнем западе ЛВБ (Бышковская площадь) и его центральной части. Было выполнено сопоставление и корреляция разрезов рассматриваемых отложений (с составлением сводных колонок), а также построены схемы их распространения на территории бассейна. Для установления состава и условий образования глинистых отложений проведены химические, термические и электронно-микроскопические анализы. 


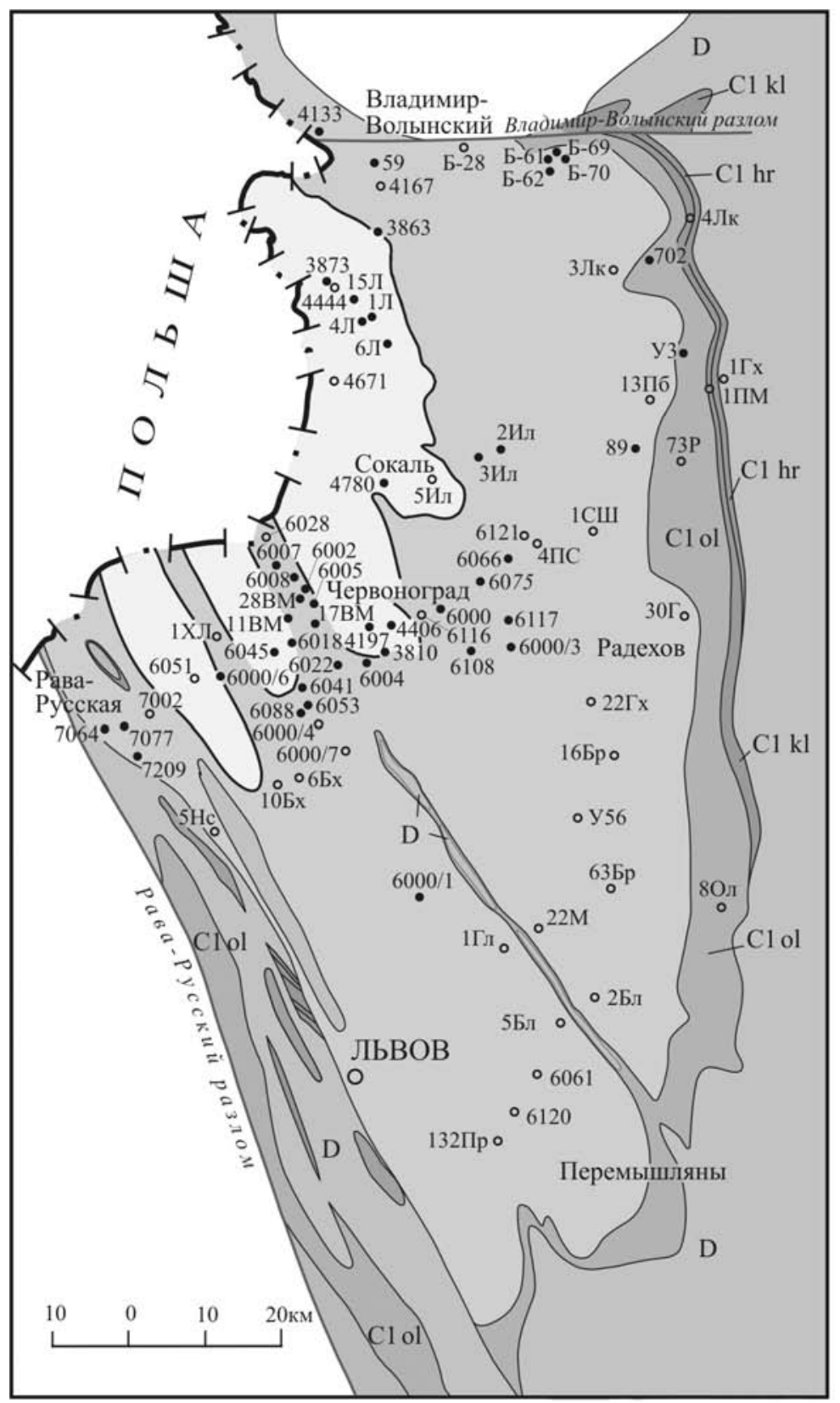

Рис. 1. Геологическая карта ЛВБ с указанием изученных разрезов и угленосности отложений турне - начала позднего визе (хоревска, куличковская и олесковская свиты):

1 - часть бассейна с промышленной угленосностью; 2 - распространение угленосной формации в принятых на сегодня границах; 3-5 - распространение отложений свит: 3 - олесковской (C1 ol), 4 - куличковской (C1 kl), 5 - хоревской (C1 hr); 6 - отложения девона; 7 - разрывные тектонические нарушения, 8 - скважины, вскрывшие отложения девона (a - угленосность отсутствует, б - с углепроявлениями

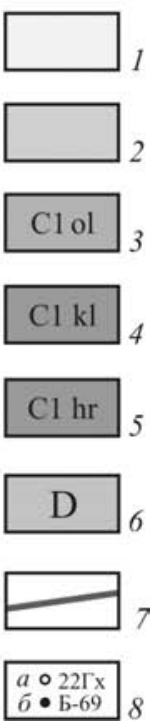

\section{СОСТАВ, СТРОЕНИЕ, ПЛОЩАДНОЕ РАСПРОСТРАНЕНИЕ ТУРНЕЙСКО-СРЕДНЕВИЗЕЙСКИХ ОТЛОЖЕНИЙ}

В ЛВБ разрез карбона начинается позднетурнейскими отложениями хоревской свиты, расположенными с размывом на образованиях девона (рис. 2). Свита представлена серыми аргиллитами, алевролитами, песчаниками. В верхней части разреза указанные породы переслаиваются с доломитизированными известняками и доломитами. В основании свиты часто залегают гравийные песчаники и гравелиты. Для хоревской свиты характерны неповсеместное распространение в центральной части и на севере бассейна, значительная изменчивость литологического состава, строения и мощности (рис. 3). Последняя достигает 295 м.

Выше с размывом залегают ранневизейские отложения куличковской свиты. В нижней части она слагается песчаниками, гравелитами с прослоями аргиллитов, а в верхней - в основном серыми, нередко пестроокрашенными высокоглиноземистыми каолинитовыми сухарными, полусухарными глинами (аргиллитами), содержащими мелкие шамозитовые конкреции. Куличковская свита (как и хоревская) развита в центральной части и на севере ЛВБ. Она отличается неповсеместным распространением на площади, изменчивостью состава и строения разреза (особенно нижней ее части), а также мощности, которая изменяется от 0 до 60 м. 


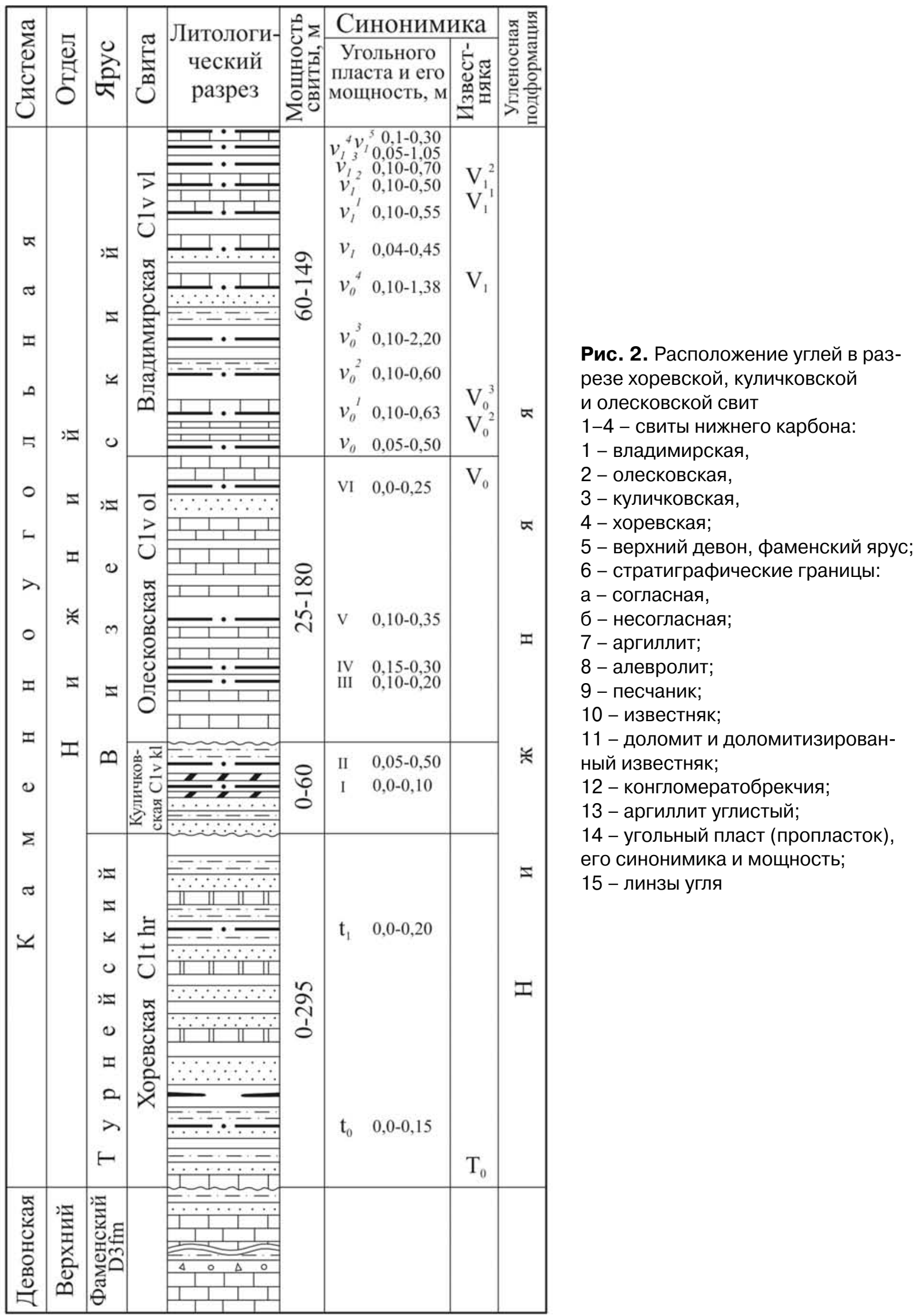

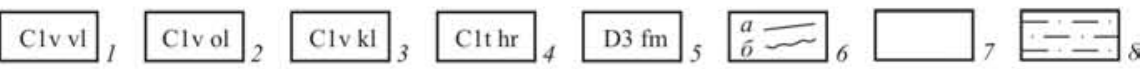

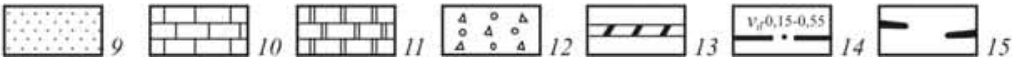



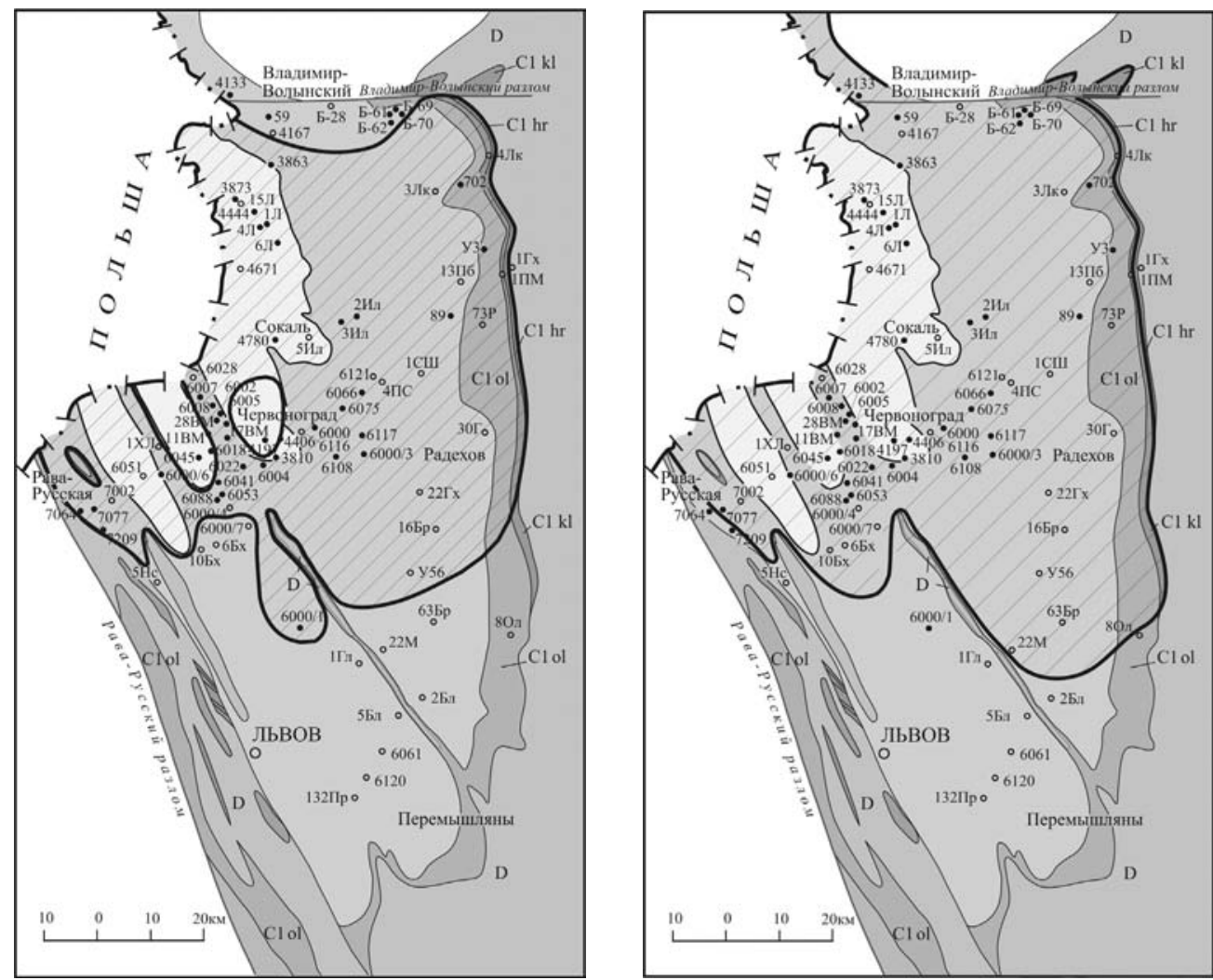

Рис.3. Схемы распространения хоревской (а) и куличковской (б) свит. Штриховкой отмечена территория неповсеместного развития свит

Олесковская свита начала позднего визе расположена на отложениях куличковской свиты, а при ее отсутствии - на размытой поверхности турнейских и раннепалеозойских образований. На преобладающей территории ЛВБ свита представлена толщей окремненных известняков мощностью до 180 м с прослоями аргиллитов. В северо-восточной части бассейна карбонатные отложения в значительной мере замещаются терригенными, и разрез свиты слагается переслаиванием аргиллитов, алевролитов и песчаников. Известняки имеют подчиненное развитие. На олесковской свите залегают поздневизейские угленосные отложения винниковской, нестеровской и владимирской свит, имеющие циклическое строение и состоящие из переслаивающихся песчаников, алевролитов, аргиллитов, известняков с пластами углей.

\section{УГЛЕНОСНОСТЬ ТУРНЕЙСКО-СРЕДНЕВИЗЕЙСКИХ ОТЛОЖЕНИЙ}

В отличие от существующих представлений об отсутствии углей в турнейских отложениях $[1-3,7,8]$, нами установлено развитие таковых по всему разрезу карбона бассейна. Первые признаки процессов карбонового углеобразования в форме редких линз и прослоев углей и углистых аргиллитов мощностью до 0,2 м обнаружены в аргиллитах и алевролитах нижней и верхней частей хоревской свиты позднего турне (Любельское, Волынское месторождения, площади Ильковичи, Литовеж и др.)

Куличковская свита (по сравнению с нижележащей хоревской) характеризуется более высокой угленосностью. На площадях Войница, Свийчев-Войница, участке Межречье-Западный и других бурением установлено наличие в свите углей мощностью 0,05-0,5 м, а также углистых аргиллитов мощностью до 0,7 м. Угли и углистые аргиллиты расположены в средней и верхней частях свиты, отличающихся широким распространением каолинитовых сухарных и полусухарных глин (аргиллитов). Есть основание полагать, что, в отличие от хоревской свиты, углепроявления которой имеют локальный характер, угли и углистые аргиллиты куличковской свиты залегают в форме невыдержанных по площади пластов, количество которых достигает пяти.

Пласты и прослои углей мощностью до 0,35 м, а также углистых аргиллитов мощностью до 0,8 м вскрыты скважинами в олесковской свите начала позднего визе. Углевмещающими породами преимущественно являются аргиллиты. Угленосность в основном приурочена к нижней и верхней частях 
разреза свиты. В общем в олесковской свите установлено более четырех пластов и прослоев углей и углистых аргиллитов. По сравнению с хоревской и куличковской свитами, угленосность олесковской свиты имеет более широкое площадное развитие. Она установлена на значительной территории ЛВБ. При этом наиболее высокой угленосностью характеризуется северная часть бассейна, где, как отмечалось ранее, происходит фациальное замещение преимущественно карбонатных отложений терригенными (Волынское месторождение, площади Ильковичи, Свийчев-Войница). Указанные особенности латерального изменения угленосности характерны также для хоревской и куличковской свит.

\section{ОБЩИЕ ЧЕРТЫ НАЧАЛА КАРБОНОВОГО УГЛЕОБРАЗОВАНИЯ}

Начало турнейско-визейского этапа углеобразования в ЛВБ в общем отличается неблагоприятными условиями для образования углей. В результате проявления бретонской фазы герцинского орогенеза в пределах изученной территории прекращается образование терригенно-эвапорито-карбонатной формации среднего и позднего девона. До позднего турне осадконакопление отсутствовало, и в условиях континентального режима происходил размыв девонских образований. Осадкообразование возобновилось лишь в позднем турне. Однако из-за значительной расчлененности палеорельефа (мощность хоревской свиты изменяется от 0 до 295 м), засушливого климата, унаследованного от позднедевонской эпохи, условия для углеобразования были неблагоприятными. Лишь на отдельных изолированных участках происходило заболачивание местности и формировались небольшие по размерам маломощные палеоторфяники. В результате морской трансгрессии в конце турнейского века терригенная седиментация сменилась карбонатной с формированием в условиях аридного климата доломитизированных известняков и доломитов.

Последовавшая за позднетурнейским наступлением моря ранневизейская регрессия определила широкое развитие в ЛВБ континентальных обстановок. Помимо этого произошли значительные изменения климатических условий. Аридный, семиаридный климат позднего девона в турне сменился гумидным климатом. Это объясняется тем, что в результате проявления активной вулканической деятельности, связанной с бретонским орогенезом, в земной атмосфере произошло значительное увеличение содержания $\mathrm{CO}_{2}$. По данным ряда исследователей $[4,6]$, в это время атмосфера характеризовалась очень высокой концентрацией углекислого газа $(0,3-0,5 \%)$, а также высокой средней

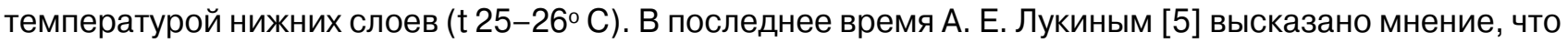
повышенная температура и влажность климата, высокое содержание в атмосфере $\mathrm{CO}_{2}$, существовавшие в самом конце-начале визе на территории ВЕП, были обусловлены мощным парниковым эффектом, возникшим в результате дыхания почвенной бактериально-актиномицетово-грибной микрофлоры. Огромная территория ВЕП от Тимана и Кольского п-ова на севере до южных границ платформы (включая Львовско-Волынский и Люблинский бассейны) располагалась в области теплого гумидного климата, сходного с таковым современных тропиков и влажных субтропиков, что благоприятствовало пышному развитию растительности. Этому способствовала также высокая концентрация в атмосфере углекислого газа. О теплом и влажном климате, существовавшем в раннем визе на территории ЛВБ и способствовавшем химическому разложению пород, а также о широком распространении континентальных (озерно-болотных) обстановок свидетельствует значительное развитие в куличковской свите высокоглиноземистых каолинитовых сухарных и полусухарных глин (аргиллитов). В совокупности это обусловило более благоприятные условия углеобразования по сравнению с поздним турне. В общем, палеогеографические обстановки и палеоклимат, существовавшие в раннем визе на территории ЛВБ, сходны с таковыми Подмосковного угольного бассейна, в котором парагенетически связанные с пластами углей озерно-болотные каолинитовые сухарные и полусухарные глины являются характерной чертой угленосной формации. Аналогичное явление наблюдается в ранневизейских угленосных формациях Припятской, Днепровско-Донецкой, Белгород-Обоянской угленосных площадей, расположенных в пределах ВЕП. Все это является основанием для рассмотрения отложений куличковской свиты в качестве нижней части карбоновой угленосной формации ЛВБ.

Широкое развитие морских обстановок, связанное с олесковской трансгрессией, определило неблагоприятные условия для углеобразования в начале позднего визе. Заболачивание местности происходило во время регрессий моря в юго-западном направлении. В начальный (трансгрессивный) этап образования олесковской свиты они имели непродолжительный характер и не распространялись далеко за пределы современной западной границы ЛВБ. Это фиксируется болотными ар- 
гиллитами со следами роста растений (стигмариевые горизонты), расположенными среди карбонатной толщи и установленными нами при описании разрезов на Бышковской угленосной площади. Формирование палеоторфяников имело локальный характер и, по-видимому, происходило на отдельных участках, занимавших более возвышенное положение. В последующий (регрессивный) этап образования олесковской свиты морские регрессии становились более частыми, обширными и продолжительными по времени. Это способствовало процессам заболачивания местности и образованию более мощных торфяников. Как отмечалось ранее, большинство углепроявлений встречено в верхней части свиты. Наиболее благоприятные для углеобразования условия существовали на северо-востоке ЛВБ. Из-за непосредственной близости к Ковельскому выступу данная территория занимала более высокое гипсометрическое положение по сравнению с остальной частью бассейна. Это обусловило увеличение роли переходных и континентальных обстановок. Периоды регрессий моря, осушения и заболачивания местности были более продолжительными, что благоприятствовало развитию процессов углеобразования. Ранне-средневизейские отложения северо-восточной части бассейна имеют все признаки паралической угленосной формации.

Залегающие выше угленосные отложения винниковской, нестеровской и владимирской свит соответствуют дальнейшему этапу развития угленосной формации ЛВБ и характеризуются промышленной угленосностью.

\section{ЗАКЛЮЧЕНИЕ}

1. Первые признаки процессов карбонового углеобразования в ЛВБ установлены в отложениях позднего турне. Процесс зарождения угленосной формации протекал постепенно и характеризовался неблагоприятными условиями.

2. Появление обстановок, благоприятствующих распространению палеоторфяников, относится к раннему визе - времени образования угленосных формаций Подмосковного бассейна, Припятской, Днепровско-Донецкой и других угленосных площадей ВЕП.

3. Позднетурнейские отложения хоревской свиты соответствуют «зародышевому» периоду развития угленосной формации ЛВБ, в связи с чем ее нижняя граница проводится нами по основанию указанной свиты.

1. Бобровник Д.П., Болдирева Т.О., Іщенко А.М. та ін. Львівсько-Волинський кам'яновугільний басейн. Вид-во АН УРСР, К.: 1962. - 145 с.

2. Бартошинская Е.С., Бык С.И., Муромцева А.А. и др. Угленосные формации карбона юго-западной окраины Восточно-Европейской платформы. - Наук. думка, Киев: 1983. - 172 с.

3. Вырвич Г.П., Гигашвили Э.П., Дубик З.Г. и др. Каменные угли Львовско-Волынского бассейна. - Выща шк., Львов: 1978. - 174 с.

4. Егоров А.И. Глобальная эволюция торфоугленакопления. Палеозой. - Изд-во Рост. ун-та, Ростов-н/Дону: 1992. - 320 c.

5. Лукин А.Е. Природа сухарных глин и эволюция био- сферы. Ст. 1. Сухарные глины - ископаемые сиаллитовые почвы и активные илы // Геол. журн. - 2002. № 2. - C. 7-23.

6. Максимов Н.М., Онищук Ю.В., Тимофеев А.А. Эволюция глобальных геологических процессов угленосного фанерозоя // Геолого-геофизические методы прогноза угленосности, Ростов-н/Дону, 1994. - С. 102-140.

7. Струев М.И., Исаков В.И., Шпакова В.Б. и др. Львовско-Волынский каменноугольный бассейн: Геологопромышленный очерк. - Наук. думка, Киев: 1984. 272 c.

8. Терентьев Е.В. Львовско-Волынский бассейн // Угленосные формации верхнего палеозоя СССР. - Недра, М.: 1975. - C. 54-79.

\footnotetext{
1 Institute of Geological Sciences NAS Ukraine, Kyiv, Ukraine

${ }^{1}$ Институт геологических наук НАН Украины, г. Киев, Украина

2 The State Geological Enterprise Zakhidukrgeological, Lviv, Ukraine

2 Производственное объединение "Запукргеология", г. Львов, Украина

${ }^{3}$ Institute of Geology and Geochemistry of Combustible Minerals NAS Ukraine, Lviv, Ukraine

${ }^{3}$ Институт геологии и геохимии горючих ископаемых НАН Украины, г. Львов, Украина

4 The Lviv-Volyn Geological Kesearch Expedition, Vladymyr-Volynsky, Ukraine

4 Львовско-Волынская геологоразведочная экспедиция, г. Владимир-Волынский, Украина
} 